\title{
IFRS, Accounting Standards in Various States
}

\author{
Dr.Ariet MALAJ \\ College University of Business Tirana Albania,Vangjel Noti,Tirane
}

\begin{abstract}
:
In the context of continuous globalization, it is essential to have common accounting standards that allow efficiency and transparency in the handling of information. The present article, applying a systematic mapping study, presents an analysis of the scientific production associated with the research topic. The results obtained generate new challenges in the accounting profession and contrast the need to distinguish the accountant as a key professional in the process of transition of financial information under IFRS.
\end{abstract}

This paper presents a theoretical discussion about the role of IFRS and varius states

Keywords: International account, IFRS, Accounting Standards Board etc.

DOI: $10.7176 / \mathrm{RJFA} / 11-17-06$

Publication date:October $31^{\text {st }} 2020$

\section{Accounting standards in Albania and SEE countries.}

Rieger (2007) reports that the SEE countries are generally characterized from a high perceived level of corruption what is often attributed to the lack of appropriate regulation tools and weak law enforcement. This implies high financial risk for foreign and domestic investors and the existence of "shadow economies" of significant dimensions. Albania, being a country within the region, reflects the same features of corruption, lack of transparency and "bribery culture".

Obviously, a sound investment environment generally requires high level of financial transparency and adequate procedures in place in order to protect the interests of minority and majority shareholders. In case of the SEE countries, which have high political risks indexes we may add to this list of the requirements also the immunity from the government and political manipulations. In such a risky environment landscape the accountants and auditors could play a key role in increasing the overall financial transparency, by preventing or detecting corruptive practices through exercising their profession with integrity and abiding to the requirements of the code of ethics. As these professionals are constantly being pressed from their employers to engage in doubtful financial/accounting transactions, to submit fraudulent financial statements, or to participate in any tax evasion schemes, they can be viewed as potential whistleblowers that could choose either to obey their employers' requests or to report these phony practices. Making such a choice usually depends on the level of their professional expertise but primarily on their integrity and other ethical and moral values they exercise in their work. The problems they face require high technical skills as well as strong beliefs to oppose old and deeply rooted corruptive accounting practices, which aim to evade taxes. Therefore the way these practitioners react to the pressures from their employers or clients more than by their professional preparation, depend on their ethical values. These ethical rules generally establish the models of their work and act as an antidote for not letting them compromise with the existing practices but choosing instead to apply correct and transparent procedures. The resistance of practitioners with professional integrity guarantees high information quality because of compliance with laws and sound financial reporting practices. Thus, the role of accountants as potential whistleblowers is extremely.

Accounting standards are very important today. They has implement in various small and medium companies.

Albania implemented its first set of 14 National Accounting Standards (NAS), which were prepared in compliance with the International Financial Reporting Standards, in 2009. The 15th standard, specifically the Accounting Standard for financial reporting by micro-entities, was added to this set in 2011 and a 16th standard, relating to the reporting for non-profit enterprises, was added in 2015. In 2014, the National Accounting Council of Albania (NACA) performed a major revision of this existing framework of NAS. The focus of this paper is to analyze the current status, as well as the development of accounting and financial reporting in Albania for the Small and Medium Enterprises (SMEs). An international standard of financial reporting for SMEs was issued by the International Accounting Standards Board but was not fully endorsed by the European Community, nor by the NACA, who instead chose to revise their current NAS. In this study, we provide a general overview of the accounting regime and platforms currently applied in Albania, by focusing on the changes over the recent years. We also depict the main differences between the IFRS for SMEs and the NAS in Albania in treatment of several elements of the financial statements.

\section{The Role of Accounting in International Business}

The purpose of accounting is to communicate the organization's financial position to company managers, investors, banks, and the government. Accounting standards provide a system of rules and principles that prescribe the format and content of financial statements. Through this consistent reporting, a firm's managers and investors 
can assess the financial health of the firm. Accounting standards cover topics such as how to account for inventories, depreciation, research and development costs, income taxes, investments, intangible assets, and employee benefits. Investors and banks use these financial statements to determine whether to invest in or loan capital to the firm, while governments use the statements to ensure that the companies are paying their fair share of taxes.

As countries developed different cultures, languages, and social and economic traditions, they developed different accounting practices as well. In an increasingly globalized world, however, these differences are not optimal for the smooth functioning of international business.

3.The Emergence of New International Accounting Standards and characteristics of International Accounting Standards and Their Implications for International Business

The International Accounting Standards Board (IASB) is the major entity proposing international standards of accounting. Originally formed in 1973 as the International Accounting Standards Committee (IASC) and renamed the International Accounting Standards Board in 2001, the IASB is an independent agency that develops accounting standards known as international financial reporting standards (IFRS)."History," International Accounting Standards Board, accessed November 26, 2010.

On one hand, having to adhere to GAAP rules as well as IFRS rules creates extra labor and paperwork for multinational firms. For example, a US company seeking to raise funds in Germany has to prepare a financial report according to IFRS accounting rules as well as US GAAP rules. Further problems arise when different country accounting rules make the financial statements look different. If the same transaction is accounted for in different ways based on different country accounting rules, the comparability of financial reports is undermined.

In some instances, the differences between US GAAP rules and IFRS are significant. For example, the lastin, first-out (LIFO) accounting method is allowed by GAAP but banned by IFRS. Some firms, such as aluminum company Alcoa, receive a tax benefit from using the LIFO method.Marie Leone, "Unfazed by IFRS," CFO, April 30, 2010, accessed August 10, 2010, http://www.cfo.com/article.cfm/14495043. If IFRS is mandated for all US companies, firms like Alcoa may need to make significant cash-tax payments. This is why US adoption of IFRS is taking time, and why the FASB and IASB are working hard to harmonize the standards.

On the positive side, other companies, like IBM, may gain greater efficiencies and stronger controls from a move to IFRS. For example, converting to IFRS would make it possible for IBM to create a globally shared service center for accounting, rather than having accounting departments in different regions.Marie Leone, "Unfazed by IFRS," CFO, April 30, 2010, accessed August 10, 2010, http://www.cfo.com/article.cfm/14495043.

US adoption of the IASB's global accounting standards would be useful to big multinational companies. Tyco International, for example, is the parent of 1,200 legal entities, 900 of them outside the United States. For Tyco, having to follow only IFRS rules would be positive, because it would enable Tyco to prepare financials on the same basis worldwide and to more freely move accounting staff from country to country and business to business.

Some smaller public companies, however, would see only costs from a move to IFRS. Davey Tree Expert Company, for example, which only does business in the United States and Canada, sees no benefits. Because the company is unlikely to ever list on any national exchange, the argument that unified standards would allow comparability of financials has no value.

An interim step toward the United States adopting IFRS is to permit US firms that operate globally to file only under IFRS, rather than under both GAAP and IFRS, thereby reducing their financial-statement preparation costs

\section{IFRS adopting in Japan.}

Since 2010, companies that meet certain criteria have been permitted to voluntarily apply IFRS Standards for consolidated financial statements in Japan. In 2013, the FSA revised its Cabinet Office Ordinances and eliminated certain requirements in order to enhance further application of IFRS Standards in Japan. As a result, the number of companies eligible to apply IFRS Standards was increased, and virtually all listed companies and unlisted companies are allowed to use IFRS Standards for consolidated financial statements.

Under the current regulation, a company may voluntarily use IFRS Standards if it meets the following criteria:

- The company discloses, in its Annual Securities Report, information regarding specific efforts to ensure that the consolidated financial statements will be prepared in accordance with 'Designated IFRS'; and

- The company allocates executives or employees with ample knowledge about 'Designated IFRS', and puts in place a structure to ensure that the consolidated financial statements will be prepared properly in accordance with Designated IFRS.

'Designated IFRS' is a set of IFRS Standards that have been designated by the Commissioner of the FSA. Each IFRS standard is made effective through the formal process of endorsement. 


\section{References}

1.Armstrong, C. S., Barth, M. E., Jagolinzer, A. D., \& Riedl, E. J. (2010). Market Reaction to the Adoption of IFRS in Europe. Accounting Review, 85(1), 31-61. doi: 10.2308/accr.2010.85.1.31

2.Albania - ROSC Accounting \& Auditing. http/worldbank.org/en.

3.Lopes, A. B. (2009). Normas internacionais de contabilidade. In J. F. R. Filho, J. Lopes \& M. Pederneiras (Eds.), Estudando teoria da contabilidade. Atlas.

4.https://saylordotorg.github.io/text_international-business/s19-01-international-accounting-stand.html 5.https://jicpa.or.jp/english/accounting/standards/https://jicpa.or.jp/english/accounting/standards/

6.http://www.ifrs.org/Home.htm.

7.https://www.google.com/search?q=Acounting+standards + in + Albania\&oq=Acounting + standards + in + Albania \&aqs $=$ chrome..69i57j012.8173j0j8\&sourceid $=$ chrome\&ie $=\mathrm{UTF}-8$

8.https://www.researchgate.net/publication/227367733_Changes_In_Financial_And_Accounting_Environment In_Albania_And_The_Impact_On_Practitioners 